\title{
ЕКОНОМІКА
}

\section{УдК: 351:336.7}

С. В. Киризюк, канд. екон. наук

Інститут економіки та прогнозування НАН України

\section{КАПТТАЛІЗАЦІЯ ФІНАНСОВИХ РЕСУРСІВ СІЛЬСЬКИХ ГРОМАД: ВИБІР СТРАТЕГІЇ}

У статті розкрито сутність процесу капіталізації фінансових ресурсів сільських громад у контексті реалізації концепції капіталів; узагальнено стратегічні підходи розвитку фінансового капіталу.

Ключові слова: сільські громади, стратегія, фінансові ресурси, фінансовий капітал.

Постановка проблеми. Проголошення незалежності, впровадження економічних реформ, отримання статусу ринкової економіки - все це свідчить про достатньо динамічні перетворення в Україні протягом менш ніж двох десятиліть. Прояви глобальної фінансової кризи в Україні підтвердили високий рівень інтеграції у світову фінансову систему, основним індикатором якої є рух капіталу. В сучасній економіці без розуміння тенденцій та прогнозування перспектив зміни вектора грошових потоків неможливо забезпечити прискорений розвиток. Гальмування зростання світової економіки, обумовлене фінансовою кризою, спричинило перерозподіл грошових потоків у життєво важливі сфери, однією з яких є сільське господарство. Незважаючи на позитивну динаміку розвитку аграрної сфери, власники головного ресурсу сільськогосподарського виробництва - землі - залишаються осторонь основних грошових потоків. Зміна економічного укладу не вплинула на залежність сільських виробників від центру, що консервує постійну дотаційність галузі та унеможливлює розвиток. Консенсусу можна досягти шляхом зміни погляду на використання ресурсів - у першу чергу, фінансів як рушія економічних змін - та їх перетворення шляхом капіталізації в сільській громаді. Проте цей процес може мати успіх лише за умови комплексного та виваженого підходу з визначенням загальної місії та стратегії розвитку фінансового капіталу сільських громад, що й було визначено метою даного дослідження.

Стан вивчення проблеми. Проблема використання та накопичення фінансів у сільській місцевості основними економічними агентами не є новими для вітчизняної науки. Загальні та часткові питання різних їі аспектів порушують провідні вчені, зокрема В.Г. Андрійчук, В.М. Геєць, О.С. Гудзь, I.О. Луніна, П.Т. Саблук, Н.С. Танклевська, С.І. Юрій, П.І. Юхименко та ін. Наприкінці XX - на початку XXI ст. американські та європейські вчені почали широко застосовувати поняття "капітал" на сплетінні теорій сільського 
розвитку та саморозвитку громад, що лягло в основу концепції капіталів громади, яка включає сім його типів: природний, фізичний, фінансовий, людський, соціальний, політичний та культурний (з англ. Community Capital Framework - CCF) [1]. У загальному можна сказати, що CCF - підхід, який дає уявлення про те, як функціонує громада. 3 огляду на запозичення із західної науки нових дефініцій та методів практичної реалізації окремих інструментів капіталізації фінансового ресурсу в сільській місцевості України (переважно у формі грантів), надзвичайно актуальним $\epsilon$ опрацювання теоретичних засад та стратегічних підходів цього процесу.

Виклад основного матеріалу. Розвиток концепції капіталів громади обумовлений об'єктивною необхідністю протистояння великим бізнес-компаніям і привласненню ними доходів та частини прав на ресурси сільських громад. У результаті була представлена нова ідея та бачення громади як банку 3 декількома "рахунками" - капіталами громади. Їх активізація можлива за умови соціальної злагодженості та згуртованості шляхом інституціалізації цих взаємовідносин, результатом яких є отримання певних вигод у формі семи капіталів громади. 3-поміж них важливу роль відіграє фінансовий капітал. Автори CCF під фінансовим капіталом громади розуміють фінансові ресурси, доступні для інвестування 3 метою нарощування можливостей громади, для підтримки розвитку бізнесу, приватного та соціального підприємництва, а також акумулювання благ для майбутнього розвитку громади [2]. У цілому під фінансовим капіталом громади розуміють інвестовані фінансові ресурси, які здатні приносити певний дохід у формі примноження ресурсів громади. Цей процес починається з ідентифікації доступних ресурсів, оцінки їх потенціалу, продовжується його реалізацією й отриманням додатково створених вигод та доходів у формі новостворених ресурсів, які можуть знову інвестуватися у розвиток, утворюючи неперервний ланцюг процесу капіталізації [3]. Наглядно оцінити відмінність капіталізації індивідуальних та колективних фінансових ресурсів можна, порівнюючи розміщення особистих коштів на депозитному рахунку в банку та формування депозитного рахунку громади (за аналогом каси взаємодопомоги на платній основі). В обох випадках ми спостерігаємо отримання вигоди у формі відсотків за користування депозитом, проте в другому випадку цьому передує деяка соціальна взаємодія між членами громади з метою домовленості щодо спільних фінансових інвестицій (нарощуючи тим самим соціальний капітал об'єднання членів громади) і разом 3 тим розширення можливостей членів громади щодо доступу до об'єднаних фінансових ресурсів. Розуміння суті процесу капіталізації фінансових ресурсів громади дозволяє виділити його характерні властивості:

- взаємодія - капіталізація фінансових ресурсів громади пов'язана 3 використанням інших типів капіталів громади. Так, наприклад, прийняття рішення щодо інвестування фінансових ресурсів здійснюється із залученням людських та соціальних ресурсів, і чим вище рівень їх капіталізації, тим вищий потенціал активізації фінансових ресурсів; 


\section{ЕКОНОМІКА}

- нагромадження - процес інвестування має приносити певні доходи або вигоди у формі нових фінансових чи інших (людських, природних та ін.) ресурсів;

- розширення можливостей - забезпечення доступу до нових фінансових ресурсів, сформованих у результаті інституційного оформлення соціальних взаємовідносин об'єднання членів громади;

- неперервний рух - передбачає безперервну капіталізацію фінансових ресурсів. Іншими словами, отримані вигоди або дивіденди від капіталізації фінансових ресурсів повинні знову бути використанні для інвестування в розвиток громади.

Розвиток сільських громад є більш глибоким та концептуальним процесом: успішність його залежить більшою мірою від стратегічних підходів, ніж від короткострокових грантів, які забезпечують тимчасову фінансову основу досягнення певних цілей громади. Суб'єкти розвитку громад (починаючи від їх лідерів і закінчуючи урядовцями) повинні розуміти важливість розробки і прийняття певної стратегії, яка формуватиме основу саморозвитку громади шляхом капіталізації доступних ресурсів.

Одним із широко застосовуваних стратегічних підходів для розвитку фінансового капіталу громад є покращення ринкового та інвестиційного середовища, суть якого полягає в ліквідації чи частковому зниженні бар'єрів, які перешкоджають залученню фінансових ресурсів потенційних інвесторів (як локальних, так і зовнішніх) у розвиток громади. Цього можна досягти, перш за все, шляхом підвищення кількості та якості інформаџї та ї̈ доступності. Проблема обмеженості інформації щодо фінансового потенціалу громади може мати принаймні два вектори: перший - відсутність інформації в самій громаді щодо своїх фінансових можливостей або можливостей залучення зовнішнього фінансування; другий - обмеженість інформації з боку можливих потенційних зовнішніх інвесторів щодо потенціалу певних громад. Вихід з цієї проблеми у збиранні інформації та формуванні баз аналітичної, наукової, публіцистичної інформації щодо фінансових можливостей громади та зацікавленості інвесторів. Застосування такого підходу на практиці може бути достатньо легким i недорогим 3 огляду на матеріальні витрати, проте вимагає достатньо чіткого керівництва та координації зусиль, технічної допомоги та науково-аналітичного супроводу. Зрештою, в Україні в цій сфері маємо достатньо високий потенціал, реалізація якого потребує лише виважених дій та співробітництва між профільним міністерством, працюючими в даному напрямі науковими установами та громадами 3 їх лідерами та керівниками на місцях.

Іншим важливим способом покращення ринкового та інвестиційного середовища сільських громад є розвиток основних фондів громади. Суть його в загальному можна звести до комплексу заходів, які включають, головним чином, розбудову/відновлення будівель та інфраструктури й гармонійне облаштування території громади. Як правило, такі проекти доволі вартісні, вимагають залучення зовнішніх інвесторів та державного сприяння. Такі заходи 
частіше використовуються для розвитку непривабливих регіонів або зменшення тиску у високорозвинених. Очевидно, що результати реалізації такого підходу можуть бути отримані лише в довгостроковій перспективі, проте їх вага матиме більш стійку основу для сталого розвитку громади. В Україні цей напрям певним чином знайшов своє застосування шляхом облаштування на сільських територіях котеджних містечок, тим самим взаємовідносини між міськими та сільськими територіями набувають ознак європейського сценарію, за яким в окремих країнах понад $50 \%$ населення проживає саме в таких нових урбанізованих поселеннях сільського типу.

Покращення ринкового та інвестиційного середовища сільських громад неможливе без забезпечення рівних можливостей їх розвитку. Реалізація заходів у межах даного напряму покликана забезпечити рівноправність, у першу чергу, між громадами з різним рівнем потенціалу. Без сумніву, більші за розміром (площею), чисельністю населення чи вигідно розташовані сільські громади мають вищий потенціал та доступ до фінансових ресурсів. Так, наприклад, досить часто гранти на фінансування тих чи інших проектів отримують інвестиційно більш привабливі громади. Функцію регулятора або гаранта в таких ситуаціях має виконувати держава та профільні міністерства, впроваджуючи певні механізми стимулювання (наприклад, шляхом підвищення частки державної участі).

Однією $з$ найбільш поширених стратегій накопичення фінансового капіталу сільських громад є розвиток кредитного ринку. Більшість сільських жителів тісно пов'язані з аграрною діяльністю, практика ведення якої потребує особливих умов залучення фінансових ресурсів у формі кредитів. Крім того, серед сільських жителів більшою мірою поширена бідність. Тому саме ця стратегія застосовується провідними світовими організаціями (ФАО, МВФ та ін.) для розвитку сільських громад шляхом ініціювання утворення фінансових організацій на базі громад (ФОГ). Для класифікації ФОГ, як правило, використовують типологію, основану на засновницькому джерелі даного фонду, тобто виділяють кредитно- та ощадно-основоположні ФОГ [4, с. 7-8]. До перших відносять ті, які були засновані на основі отримання коштів ззовні для цілей організації, а потім, якщо виникла така потреба, залучали заощадження членів громади. Другі, навпаки, були ініційовані членами громади на основі об’єднання їх заощаджень та спільного управління ними для цілей організації, а згодом отримали доступ до зовнішніх кредитних ресурсів (комерційних банків, донорів тощо). Часто ФОГ не мають зовнішніх фондів, і функціонують виключно на основі внутрішніх фінансових ресурсів громади. Для ФОГ характерні певні ознаки: по-перше, засновані на членській участі жителів громади; по-друге, діють на обмеженій території, як правило, однієї громади; по-трете, досить часто, не мають юридичної форми. У США найбільшого поширення набули різні кредитні фонди, засновані на приватній, колективній, державній чи змішаній формах власності. Серед них можна виділити чотири найбільш поширені типи: 


\section{ЕКОНОМІКА}

- Об'єднання кредитування розвитку громади - функціонують як звичайні кредитні установи, але на обмеженій, чітко визначеній території. Надають індивідуальні позики суб'єктам, які обмежені у доступі до кредитних ресурсів через інші фінансово-кредитні установи.

- Банки розвитку громади - неприбуткові організації, засновані на приватній основі, метою яких є підтримка розвитку сусідніх нерозвинених територій.

- Фонди оборотних позик - державні кредитні організації, які надають позики для розвитку, розширення або підтримки бізнесу у певній громаді або, як правило, на певній встановленій території.

- Фонди мікрокредитування - діють переважно з метою підтримки розвитку підприємництва серед молодого населення чи безробітних.

В країнах, що розвиваються, зокрема в Індії, та середньо-азійських країнах (колишніх республіках СРСР) мікрокредитування отримало дещо новий виток розвитку після запровадження системи групових кредитів. Необхідність такого механізму обумовлена низькотоварністю та малим розміром господарюючих суб'єктів, які не відповідали необхідним критеріям. Тому було запропоновано альтернативний варіант - кругової поруки. Так, наприклад, в Таджикистані колективні кредити надаються групам від 3 до 10 чоловік. В результаті кожен член групи несе кругову поруку за повернення кредиту, що стимулює кожного з них до розвитку взаємопідтримки та духу колективізму. Як правило, такі кредити надаються для ведення, розширення або диверсифікації сільськогосподарської діяльності або групам жінок [5].

Найбільшого поширення в світі набули ощадні ФОГ. Серед їх типових видів можна виділити сільські ощадні об'єднання (нечисленні обмежені в часі об'єднання заощаджень для надання позик його членам), групи взаємопідтримки [6] (на відміну від попереднього виду, залучають зовнішні ресурси i формують розгалужену мережу за межами населеного пункту та регіону для консолідації ресурсів) та найбільш розвинені - сільські фінансові об'єднання та кооперативи [7] (крім фінансування членів здійснюють підтримку і розвиток соціальних й економічних програм в громаді, наприклад, медична допомога, підтримка іригаційних систем, навчання тощо.

Підсумовуючи теоретико-прикладні аспекти розвитку ФОГ, треба відмітити, що ключовими факторами успіху та високої результативності їх $є$ :

- самоініціативність членів громади;

- лідерство та активна участь;

- обмін ідеями;

- соціальна спрямованість розвитку;

- забезпечення технічної допомоги та державне сприяння;

- розвиток регіональних систем та мереж.

Стратегія розвитку кредитного ринку може бути найбільш прийнятною для України з огляду на низький розвиток фінансового ринку та поширення 
фінансових послуг у сільській місцевості. Адже, як підтверджує закордонна практика, розвинуті ФОГ можуть надавати широкий спектр фінансових послуг та гарантувати високу якість та ефективність роботи. Ключову роль у розвитку фінансового капіталу сільських громад України можуть відіграти ощадні ФОГ. В Україні лише 7\% населення використовує депозитні рахунки як інструмент капіталізації заощаджень, а понад половина - тримає вільні кошти вдома $[8$, с. 275]. Подолання цієї тенденції може бути здійснено саме через утворення ощадних ФОГ, адже, по-перше, їх організаційна структура, органи управління формуються переважно з сільських мешканців. Тому достатньо виникнення ідеї серед лідерів громад та підтримці ії принаймні частиною сільських жителів для запуску роботи ФОГ. По-друге, українці володіють достатніми тимчасово вільними фінансовими ресурсами (за оцінками академіка НАНУ В.М. Гейця "...у населення $є$ від 40 до 60 млрд дол." ${ }^{1}$ ), частина 3 яких може бути інвестована 3 метою задоволення як індивідуальних, так і колективних цілей розвитку. Окремі моменти розвитку кредитних спілок територіальних громад були прописані у проекті Стратегії розвитку фінансового сектору України до 2015 року [9]. Проте діяльність ФОГ не обмежується фінансовими послугами, а може виходити за їх рамки, тому це питання вимагає розробки окремої стратегії, де будуть прописані всі питання.

Зниження ризиків. Можливість доступу до кредитних ресурсів значною мірою обумовлюється потенційними ризиками, закладеними специфікою суб'єкта кредитування. Інвестиції в розвиток громади мають високий ступінь ризику. Крім того, більшість проектів, які реалізовуються в громаді, мають на меті отримання, в першу чергу, не фінансово-економічних, а суспільних та соціальних ефектів. 3 огляду на це залучення фінансових ресурсів приватних інвесторів значно обмежується. Для подолання даної проблеми в розвинутих громадах використовують поширені в банківській практиці фінансові механізми зниження ризиків:

- Застава - специфічний інструмент, який гарантує інвестору повернення вкладених коштів в разі настання визначених угодою умов. Як правило, як заставу громади використовують спільне (комунальне) майно та власність або об'єднані приватні активи їх членів.

- Кредитні гарантії - інструмент, який базується на засадах гарантій третіх суб'єктів повернення частини або всього обсягу кредитних ресурсів. Кредитні гарантії можуть надавати приватні особи, інші громади або фонди, а також держава.

- Страхування від неповернення кредиту - інструмент, який може використовуватися як кредитором, так і позичальником. Страхування здійснюється на платній основі, що значно зменшує привабливість його застосування у практиці розвитку громад.

${ }^{1}$ http://dt.ua/articles/56358

92 


\section{ЕКОНОМІКА}

Реалізація стратегії зниження ризиків розвитку фінансового капіталу в Україні є достатньо актуальною з огляду на важливість даного критерію під час отримання доступу громадами до зовнішнього фінансування, в першу чергу, комерційних кредитів.

Стратегія податкового стимулювання застосовується, як правило, державними органами управління або самоврядними органами на місцях. Така стратегія найбільш виправданою $є$ у випадках з найменш розвиненими та неперспективними громадами, територіями чи регіонами. Це - прямий механізм вливання (інвестування) фінансового капіталу у розвиток громади. Стратегія податкового стимулювання може реалізовуватись у декілька способів:

- Податковий кредит - інструмент, суть якого полягає у зменшенні податкових зобов'язань на суму, витрачену суб'єктом на придбання товарів та послуг або інвестованих у розвиток громади.

- Податкові виключення - полягає у зменшенні суми доходу, що підлягає оподаткування. Наприклад, виключення оподаткування доходів, отриманих від придбання цінних паперів, випущених органом самоуправління.

- TIF (Tax Increment Financing) - інструмент, суть якого полягає в отриманні додаткових податкових надходжень від зростання вартості будь-яких фондів або власності в результаті розвитку інфраструктури, будівництва тощо. Наприклад, громада приймає рішення про виділення частини земель під розвиток місць для кемпінгу за рахунок коштів громади. Залучені туристи принесуть додаткові доходи громаді у вигляді податків не лише від використання місць для кемпінгу, а й місцевим підприємцям-торговцям, ремісникам тощо. Цей інструмент знайшов широке застосування у практиці розвитку громад в США і згодом поширився серед громад країн $С$.

Прийняття рішення про використання податкової стратегії розвитку фінансового капіталу громади має бути виваженим і підкріплене аналізом збільшення капіталу залежно від типу вибраної стратегії та оцінки втрат та переваг iiï впровадження. Просування податкової стратегії можливо лише за умови високого рівня політичної волі - розвиненого політичного капіталу.

Фінансова кооперація - стратегія, яка полягає у збільшенні числа зацікавлених суб' єктів інвестування розвитку громади, розширені кола взаємозв'язків, що підвищує ефективність та знижує ризики, а головне підвищує доступність громади до фінансового капіталу для її розвитку. Реалізація стратегії фінансової кооперації може здійснюватись шляхом розвитку фінансових посередників. Громади (або частіше державні органи влади) ініціюють утворення фінансових посередників, які займаються формуванням бази доступних фінансових ресурсів із зовнішніх джерел, які можуть бути використані для підтримки розвитку громадських ініціатив. Необхідність утворення таких посередницьких структур обумовлена відсутністю кваліфікованих кадрів у громаді або їх низьким рівнем підготовки. Крім того висококваліфіковані спеціа- 
лісти мають кращий доступ до інформації щодо потенційних інвесторів, що підвищує ефективність реалізації такого інструмента кооперації.

Іншим варіантом фінансової кооперації є розвиток вторинних фінансових ринків. Необхідність їх виникнення обумовлена обмеженими можливостями однієї громади (території, регіону) у консолідації фінансових ресурсів та об'єктів інвестування. Даний інструмент є більш складним в організації, вимагає консолідації зусиль щодо розробки законодавчого забезпечення, організаційної структури, кадрів, системи гарантування - повного спектра умов, що характерні для розвиненого фінансового ринку.

Висновки. Розуміння розвитку села за останні двадцять років суттєво трансформувалося. На зміну регіональному підходу прийшов новий, який зводиться до висунення сільської громади на перший план. Ідеологічна відмінність його полягає у розумінні громади як певного "банку капіталів", що детально розкрито у концепції капіталів громади. Тому громада розглядається як самодостатня одиниця національної економіки з різним рівнем ресурсів, необхідних для іiї розвитку шляхом капіталізації ії активів.

Поряд 3 людським капіталом важливу роль у розвитку громади відіграє фінансовий капітал. Під фінансовим капіталом громади слід розуміти гроші, високоліквідні фінансові ресурси та доступ до них, отриманий в результаті інституалізації соціальних відносин між членами громади, що здатні приносити прибутки та додаткові ефекти у формі нових ресурсів громади. Сучасна теорія та практика передбачає велику кількість різних концепцій його розвитку. Детальне вивчення основних 3 них дозволяє зробити висновок, що прийнятність тієї чи іншої стратегії обумовлено, в першу чергу, рівнем суб'єкта, приймаючого рішення: від мікрорівня (громади) до макрорівня (держави). Проте більшого успіху та результату можна досягти при комплексному поєднанні зусиль на всіх рівнях для ефективного впровадження певної стратегії. Обмеженість впровадження окремих стратегій може бути обумовлена як внутрішніми (територіальна розосередженість, малі розміри громад, що особливо характерно для України, адже понад 50\% сіл мають менше 300 жителів), так і зовнішніми факторами (фінансова криза). Однією з найбільш успішних і поширених стратегій розвитку фінансового капіталу є стратегія розвитку кредитного ринку. Результати іiі впровадження можна простежити по всій земній кулі, що обумовило розвиток досить різних фінансових організацій громади: від неформальних ощадних груп (африканські країни) до мереж фінансових об'єднань та кооперативів (азійські та північноамериканські країни). Незважаючи на географічну та типологічну широту ФОГ для успішного й результативного впровадження та діяльності необхідно усвідомлювати і враховувати природу їх формування, довго тривалість розвитку, що вимагає з боку державних органів управління заходів підвищення людського та соціального капіталу сільських громад, технічного та науково-аналітичного супроводу протягом тривалого періоду. Розвиток ощадних ФОГ у сільській місцевості України може бути найбільш ефективним і прийнятним інструментом капіталізації фінансових ресурсів сільських 


\section{ЕКОНОМІКА}

жителів. Позитивними передумовами їх розвитку є наявність значних фінансових ресурсів населення, проте для їх активізації потрібно подолати певні перешкоди внаслідок низького рівня соціального капіталу окремих громад, вирішення питання організаційних форм (прибуткового статусу передусім) фінансових організацій громад, а також поширення інформації що їх діяльності. Ці питання вимагають першочергового вирішення для забезпечення можливості їх розвитку та поширення на всій території України.

1. Flora, C. Rural communities: Legacy and change / Flora, C., \& Flora, J. (with Fey, S.). -2 nd ed. - Boulder, CO: Westview Press. 2004.

2. Community Capitals [Електронний ресурс]. - Режим доступу : http:/ www. soc.iastate.edu/staff/cflora/ncrcrd/capitals.html

3. Бородіна O.M. Теоретичні основи сільського розвитку на базі громад: капіталізація активів / О.М. Бородіна, С.В. Киризюк, О.В. Риковська // Економіка АПК. - 2011. - № 5. - С. 153-160.

4. Ritchie A. Community-Based Financial Organizations: A solution to Access in Remote Rural Areas? Agriculture and Rural Development Discussion Paper 34 [Електронний ресурс] / A. Ritchie. - Washington, DC : World Bank, 2007. - Режим доступу : http://siteresources.worldbank.org/INTARD/Resources/combasedfinance.pdf 5. Деятельность по микрофинансированию в Таджикистане [Електронний pecypc]. - Режим доступу : http://www.akdn.org/tajikistan_microfinance_r.asp 6. Ajay Tankha Self-help Groups as Financial Intermediaries in India: Cost of Promotion, Sustainability and Impact [Електронний ресурс]. - Режим доступу : http://w.sa-dhan.net/Adls/Microfinance/PerspectiveMicrofinance/Self-helpGroupsas Financial.pdf

7. Walaitat Worakul Community-based microfinance: An Empowering Approach Towards Poverty Alleviation and Community Self-Reliance, UNDP Thailand [Електронний pecypc]. - Режим доступу : http://www.undp.or.th/download/Microfinancebook.pdf

8. Томашик Л.С. Напрями збільшення заощаджень в Україні: теоретичні та емпіричні оцінки / Л.С. Томашик // Наук. вісник НЛТУ України. - 2011. Вип. 21.17. - С. 274-279.

9. Стратегія розвитку фінансового сектору України до 2015 року (проект) // Україна фінансова. Інформаційно-аналітичний портал Українського агентства фінансового розвитку [Електронний ресурс]. - Режим доступу : www.ufin.com. ua/koncepcia/002.doc

\section{Транслітерований список джерел}

1. Flora C. Rural communities: Legacy and change / Flora, C., \& Flora, J. (with Fey, S.). -2 nd ed. - Boulder, CO: Westview Press. 2004. [in English]

2. Community Capitals [Electronic resource]. - Mode of acces: http://www.soc. iastate.edu/staff/cflora/ncrcrd/capitals.html [in English] 
3. Borodina O.M. Teoretychni osnovy sil's'kogo rozvytku na bazi gromad: kapitalizacija aktyviv / O.M. Borodina, S.V. Kyryzjuk, O.V. Rykovs'ka // Ekonomika APK. - 2011. - № 5. - S. 153-160. [in Ukrainian]

4. Ritchie A. Community-Based Financial Organizations: A solution to Access in Remote Rural Areas? Agriculture and Rural Development Discussion Paper 34 [Electronic resource] / A. Ritchie. - Washington, DC : World Bank, 2007. - Mode of acces: http://siteresources.worldbank.org/INTARD/Resources/combasedfinance.pdf [in English] 5. Dejatel'nost' po mikrofinansirovaniju v Tadzhikistane [Elektronnij resurs]. Rezhim dostupu : http://www.akdn.org/tajikistan_microfinance_r.asp [in Russian] 6. Ajay Tankha Self-help Groups as Financial Intermediaries in India: Cost of Promotion, Sustainability and Impact [Electronic resource]. - Mode of acces: http://w.sa-dhan.net/Adls/Microfinance/PerspectiveMicrofinance/Self-helpGroupsas Financial.pdf [in English]

7. Walaitat Worakul Community-based microfinance: An Empowering Approach Towards Poverty Alleviation and Community Self-Reliance, UNDP Thailand [Electronic resource]. - Mode of acces: http://www.undp.or.th/download/Microfinancebook.pdf [in English]

8. Tomashyk L.S. Naprjamy zbil'shennja zaoshhadzhen' v Ukrai'ni: teoretychni ta empirychni ocinky / L.S. Tomashyk // Nauk. visnyk NLTU Ukrai'ny. - 2011. Vyp. 21.17. - S. 274-279. [in Ukrainian]

9. Strategija rozvytku finansovogo sektoru Ukrai'ny do 2015 roku (proekt) // Ukrai'na finansova. Informacijno-analitychnyj portal Ukrai'ns'kogo agentstva finansovogo rozvytku [Elektronnyj resurs]. - Rezhym dostupu : www.ufin.com. ua/koncepcia/002.doc [in Ukrainian]

Отримано 25.06.12

Киризюк С., канд. экон. наук

КАПИТАЛИЗАЦИЯ ФИНАНСОВЫХ РЕСУРСОВ СЕЛЬСКИХ ОБЩИН: ВЫБОР СТРАТЕГИИ

В статье раскрыто сущность процесса капитализации финансовых ресурсов сельских общин в контексте реализации концепции капиталов; обобщено стратегические подходы развития финансового капитала.

Ключевые слова: сельские общины, стратегия, финансовый капитал.

\section{S.V. Kirizuk, Candidate of Economic Sciences \\ CAPITALISATION OF FINANCIAL RESOURCES OF RURAL COMMUNITIES: SELECTION OF STRATEGY}

Article reveals the essence of the capitalization of the financial resources of rural communities in the context of realization of concept of capitals, summarizes strategic approaches to the development of financial capital.

Key words: rural communities, strategy, financial resources, financial capital. 